\title{
RELATIONSHIP QUALITY IN EARLY ADULT INDIVIDUALS THAT ARE IN LONG-DISTANCE RELATIONSHIPS
}

\section{Danny Sanjaya Arfensia1, Putu Diana Wulandari, Respianto, Satria Kamal Agassi, Riris Ristiana, Putu Vidyastitha Wiguna, Wiwin Hendriani, Ilham Nur Alfian}

\author{
Universitas Airlangga, Surabaya, Indonesia \\ dannysanjaya@staf.unair.ac.id
}

\begin{abstract}
Technological advances make communication easier for couples who have long-distance relationships. However, the quality of the relationship between a couple who are apart and being together is not necessarily the same, especially when it comes to intimacy. This study aims to determine the quality of relationships in early adults who undergo long-distance relationships. The theory used in this study is the relationship quality theory Fletcher, Simpson, \& Thomas (2000). The qualitative research method was chosen with a case study approach that focuses on how individuals interact in long-distance relationships. Data collection techniques in this study using interviews. The subjects of this study were 2 early adult couples who had a long-distance relationship between Surabaya and outside Surabaya. The couple had been in a relationship for at least 1 year. The data analysis technique used in this research is the thematic analysis technique theory-driven. The results indicate that respondent 1 shows relationship satisfaction despite feeling uncomfortable with the relationship being undertaken. Respondent 2 showed relationship satisfaction but did not appreciate his partner's achievements. From these results can be concluded that the quality of the relationship of each partner who has a long-distance relationship is different.
\end{abstract}

Keywords: early adulthood, intimacy, long-distance relationship

Abstrak; Kemajuan teknologi memudahkan komunikasi pada pasangan yang menjalani hubungan jarak jauh. Kualitas hubungan pasangan tersebut belum tentu sama bila dibandingkan dengan pasangan yang dapat bertemu secara langsung, terutama dalam hal keintiman. Tujuan penelitian ini adalah mengetahui kualitas hubungan pada individu dewasa awal yang menjalani hubungan jarak jauh. Teori yang digunakan dalam penelitian ini adalah teori kulaitas hubungan Fletcher, Simpson, \& Thomas (2000). Metode penelitian kualitatif dipilih dengan pendekatan studi kasus yang fokus pada bagaimana individu tersebut melakukan interaksi dalam menjalin hubungan jarak jauh. Teknik pengumpulan data pada penelitian ini menggunakan wawancara. Subjek penelitian ini merupakan 2 pasangan dewasa awal yang menjalin hubungan jarak jauh antara Surabaya dan luar Surabaya dan pasangan tersebut telah menjalin hubungan minimal 1 tahun. Teknik analisis data yang digunakan dalam penelitian ini adalah teknik analisis tematik theory-driven. Hasil penelitian menunjukkan bahwa responden 1 menunjukkan kepuasan hubungan meskipun merasa tidak nyaman dengan hubungan yang dijalani. Responden 2 menunjukan kepuasan hubungan namun kurang mengapresiasi prestasi pasangannya. Dari hasil tersebut dapat disimpulkan bahwa kualitas hubungan setiap pasangan yang menjalin hubungan jarak jauh berbeda.

Kata kunci: dewasa awal, keintiman, hubungan jarak jauh.

1 Corresponding author 


\section{Introduction}

In early adulthood, exploration in life will focus on the search for love, and according to Arnett (2000), this topic is the most discussed. Early adulthood is a period of transition from adolescence to adulthood, referred to as emerging adulthood, namely the developmental period in late adolescence leading to the twenties with an age range of 18-25 years. At this time various possibilities regarding love, work, and views of the world will be explored and tend to change (Erikson, 1958; Rindfuss, 1991 in Arnett, 2000).

People in early adulthood realized this by establishing relationships that involve physical and emotional closeness accompanied by the intensity and quality of relationships that are more mature than at previous stages of development, adolescence. For adolescence, the exploration of love is just for mere entertainment such as looking for friends to a party, dance and hang out with. However, they consider being in a romantic relationship at the early adulthood stage, not just entertainment. Still, they have also entered the phase of exploring the potential for emotional and physical intimacy. Exploration about love at this stage is more likely to involve a deeper level of intimacy and tend to answer questions such as in my opinion what kind of person and what kind of person you want to be friends with for life (Arnett, 2000).

Early adult individuals find partners in these relationships by different methods. The method of finding a partner is based on trends at the year in which the individual lives and develops (Simanjuntak, 2011). With the development of today's technology, communication between individuals is carried out through cyberspace to cover distances and open up opportunities for couples to establish relationships remotely, long-distance relationships. Based on the earlier interview by the researcher, we knew that long-distance partners could do the initial introduction by meeting face-to-face or long-distance acquaintances.

A long-distance relationship can be called an LDR has a wide range of definitions, one of which is they who have the hope to continue a close relationship, but the opportunity to communicate is limited by geographical distance (Neustaedter and Greenberg, 2011). Then in another study, long-distance relationships were also defined based on how long individuals were separated and the physical distance that separated them (Kidenda, 2002). Even expressly, a minimum distance has been set, which can be said to be a long-distance relationship or based on a location that is outside a particular area, and some argue based on the separation between two different countries (Kidenda, 2002). Categorization of couples who have long-distance relationships has been formulated based on differences in time and distance (Holt and Stone, 1988 in Kidenda, 2002). The first category based on the frequency of how long apart is divided into three times $(0$, less than 6 months, more than 6 months). The second category based on the frequency of meetings is divided into three times (more than once a week, once a week to once a month, less than once a month). The third category is based on the distance separating (0-1 miles/ 0-1.6 km, 2-294 miles/ 3.2-470 km, more than 250 miles/ more than $400 \mathrm{~km}$ ). 
The consequence that arises from the condition of distance limitations is a decrease in the degree of mutual dependence on people who are in longdistance relationships (Cieleszky, 2017). Mutual dependence itself is the extent to which partners influence each other's beliefs and the enactment of mutually preferred behaviour (Kelley and Thibaut, 1978 in Cieleszky, 2017). In addition, this also affects the decreasing level of interdependence in achieving a relationship such as having a fun time together or even achieving a relationship. Even so, if in the past when distance separated it meant that they were completely separated and could not contact each other. However, nowadays there is a lot of information and communication technology and the ease of transportation makes the opportunity to be able to meet increases when experiencing a relationship that is separated by distance (Cieleszky, 2017). Perhaps this will also affect the definition and characteristics of long-distance relationships in the future.

With advances in technology and information today, it is easier for couples who are in long-distance relationships to communicate, however, the couple has a low frequency of face-to-face intensity, which impacts the lack of partners knowing the complete picture of their partners. In addition, in the initial research conducted by researchers, the study found that partners would not provide the intimacy needed by their partners, even though intimacy is one of the determinants of relationship quality. Relationship quality is an individual's subjective evaluation of their partner in a relationship (Fletcher, Simpson, and Thomas, 2000). Subjective evaluation can be positive or negative, but from a humanistic point of view, regardless of whether the individual views a relationship as positive or negative, the couple is free to determine the level of quality of the relationship they want (Aanstoos, Serlin, and Greening, 2000). Individuals who are in a relationship will certainly develop and maintain the quality of the relationship with their partner so that the couple is free to make positive efforts to improve the quality of the relationship.

The quality of the relationship of couples who have long-distance relationships can indeed be pursued, but relationships are also difficult to live with because they are more at risk of experiencing problems due to differences in the distance (Guldner and Swensen, 1995). National LDR held a survey in 2012 with 1.504 respondents. The survey found that around $63 \%$ of LDR relationships ended while still in a relationship, and only about $10 \%$ were successful and able to proceed to a higher stage. National LDR found that the cause of long-distance relationships ending was infidelity by $33 \%$, relationships are no longer harmonious by $30 \%$, loneliness by almost $20 \%$, and less than $10 \%$ blaming unchanneled lust (Manampiring, 2014). Research of Dr. Greg Guldner from the Center for the Study of Long Distance in the United States found that around $70 \%$ of couples failed to have long-distance relationships because of difficulties in the changes that occur and, in the end, only able to last for six months ("Long Distance Relationship Mungkinkah?", 2011).

In contrast to previous studies which showed results in the form of failure of couples in long-distance relationships, research conducted by Kelmer, Rhoades, Stanley, and Markman (2013) researched 
with 870 respondents showed that longdistance relationships have a higher level of relationship quality on several relationships quality variables, such as higher levels of dedication to their relationship and lower levels of feelings of restraint. This study wants to provide an overview to the reader of how the quality of relationships in early adulthood is an experience or a phase for a pleasant life, but it is challenged when a young couple who are in a relationship must be separated by distance but still carry on their relationship. Similar research from Indrawati, Sani, and Ariela regarding the relationship between expectations and relationship quality in young adults, found a significant association between expectations and relationship quality. They conducted the research quantitatively with The Hope Scale and The Perceived Relationship Quality Component instruments.

Research on intimacy has done a lot so far. Research on this topic has been carried out in early adult individuals in long-distance dating with different cities, and the subject of qualitative research is a male partner. In this study, the researcher showed quite good intimacy in the relationship because the participants had almost all components of intimacy, and the factors of breadth, openness, and depth were factors that influenced it (Yudistriana, Basuki, and Harsanti, 2010). Meanwhile, in other studies, the focus is more on the communication pattern variable (Okfriana, 2016) and the commitment variable (Lesmana, 2010). Both studies were conducted using a quantitative method approach.

Research carried out from countries outside Indonesia itself found that the study focused on research that tried to photograph intimacy from the perspective of 5 adult individuals who had had children that occurred in the environment of Filipino migrants (Parrenas, 2005). In his research, Parrenas shows one of the results of his study that individuals who have deficiencies in communication skills will find it difficult to build intimacy with other individuals. The subsequent research by Holmes (2004) tried to look more at longdistance relationships from the aspect of individualization, gender, and of course, the intimacy of the partners he interviewed. It appears that the study succeeded in showing that women in couples who are in long-distance relationships are important figures who are responsible for maintaining togetherness in relationships, especially in the aspect of intimacy.

Neustaedter and Greenberg (2011) explain that in any relationship situation, long-distance relationships that are carried out through video conversations can be an opportunity for couples who experience the relationship to increase intimacy and reduce the idealism built by each individual in the couple. Although the challenge for the media is when the aspects of time zone differences, video technicalities, and the inability to see the full physical picture of each partner emerge. From this latest research, researchers are trying to provide alternative solutions for individuals who are in long-distance relationships.

This study wants to find out, explore, and provide an overview to the reader how the quality of relationships in early adult individuals who undergo longdistance relationships and as a person at the stage that is the most focused on searching for love. Individuals who are in a relationship will certainly develop and 
maintain a quality relationship with their partner. This paper is essential to study, mainly because previous studies only photographed couples from one side so that researchers tried to see from both sides. In this study, the researcher wants to see the complete picture of intimacy with a much more usual method to describe intimacy, a qualitative approach. Therefore, the researcher made sure the description of intimacy and the factors that influence decision making, and how to maintain the relationship in the sociocultural context in Indonesia. Suppose indeed, and it can be representative enough to explain the picture of intimacy. In that case, it will be a significant advantage for the following research to find alternative solutions in making this relationship effective in the cultural context in Indonesia.

The theoretical benefit of this research is as a source of information to develop psychological science, especially in Developmental Psychology and Social Psychology related to the quality of relationships in early adults who undergo long-distance relationships. It also can be used as a reference for further researchers who want to explore the topic of relationship quality and long-distance relationships. Finally, the practical benefit of this research can be applied to individuals who are in long-distance relationships because this study can provide input to build a harmonious relationship. For individuals considering undergoing long-distance relationships, the results can be regarded as the quality of relationships needed when choosing to have a long-distance relationship.

\section{Research Methodology}

The method used in this research is a qualitative research method. This type of qualitative research is an approach to exploring and understanding individuals or groups' meaning related to social or human problems (Creswell, 2007). Qualitative research methods are expected to get more mixed results on the topic of research, which is intimacy in couples in long-distance relationships. Researchers use qualitative research because the problem or research topic taken needs to be explored further. Qualitative research is also used because it requires a complex detailed understanding of the problem at hand (Creswell, 2007). This detail can only be formed by talking directly to the subject, visiting the subject's place, and allowing them to tell their story without feeling burdened by what the researcher expects and what the researcher has read in the literature (Creswell, 2007).

Qualitative research is conducted when the researcher wants to understand the context in which the participants in the study address the problem. Qualitative methods in this study are expected to understand relationships that focus on intimacy in young adults who have longdistance relationships in Surabaya and outside Surabaya. The approach used in this research is a case study. Case study research is a qualitative approach. The researcher explores a constrained system (cases) or several constrained systems (cases) over time through in-depth and detailed data collection involving multiple sources of information and reporting case descriptions and case-based themes. Examples of sources of information are observations, interviews, audiovisual 
materials, and documents and reports (Creswell, 2007).

This analytical study can be divided into individual and group analysis studies (Moleong, 2013). The main thing in choosing and making decisions about the correct unit of analysis is deciding what the researcher wants to convey at the end of the study (Patton, 2002). The unit of analysis used in this study is at the individual level by focusing on how the individual interacts with the surrounding environment; in this case, the environment around the individual is a long-distance relationship carried out by the individual. The level of individual analysis means collecting what happens in their activities, what influences them, and how individuals behave (Moleong, 2013).

In qualitative research, the research respondents are more or more involved in events and have the essential information needed in research (Ahmadi, 2014). Therefore, in research, the criteria for respondents in this study are divided into respondents who convert because of their desires and respondents who convert because of environmental factors: $a$. Respondents' age was 18-25 years old; $b$. Have been in a relationship for at least 1 year; c. Gender is not restricted; $d$. Education is not restricted; e. Establish a long-distance relationship between Surabaya and outside Surabaya.

In this study, the researcher used purposive and snowball sampling as a sampling technique because the researcher wanted the subjects to be the most involved in events and or had the information needed in the study. Purposive sampling is a type of sampling that is accepted for special situations (Ahmadi, 2014). Respondents in this study will only use respondents with predetermined criteria that are by the study's objectives. Snowball sampling is a method for identifying and sampling or selecting cases in a network (Ahmadi, 2014).

Data mining techniques used in qualitative research emphasize the types of interview techniques, especially indepth interviews (Ahmadi, 2014). In Ahmadi (2014), Patton also said that the primary way qualitative methodologists use to understand people's perceptions, feelings, and knowledge is through indepth and intensive interviews. Therefore, the technique used in this research is an interview. The data obtained were obtained through interview and observation techniques from the respondent's statements and other people included in the respondent's experience.

The data analysis technique used in this research is the theory-driven thematic analysis technique. Thus, there are several stages, namely:

1. Developing a coding manual that contains a code label, a definition of the theme used, a description of how to know when the theme occurs;

2. Test the reliability of the code used;

3. Summarizing the data and identifying the initial data;

4. Apply the code and add the code;

5. Linking codes and identifying themes;

6. Reinforce and legitimize the coded theme.

The following is the manual code that the researcher uses in condensing verbatim data:

Table 1

Code Manual

\begin{tabular}{ll} 
Code & Theme \\
\hline Quality of & 1 Label: Relationship Satisfaction
\end{tabular}

Relationship Definition: The state in which the couple feels their relationship is 


Code Theme
going according to what they
expect. The extent to which the
partner meets the most needs a
vital individual that can lead to
happiness in the relationship.
Indicators:
- Individuals can fulfill the
- $\begin{aligned} & \text { Individuals can explain the } \\ & \text { needs needed by their } \\ & \text { partners } \\ & \text { Individuals can be happy } \\ & \text { every time their partners } \\ & \text { achieve specific } \\ & \text { achievements }\end{aligned}$

2 Labels: Commitment

Definition: The decision to love others and maintain that love continuously by being loyal to his/her partner.

\section{Indicators:}

- Individuals keep promises that have been discussed

- Individuals have no desire to cheat

- Individuals do not have the urge to lie

- Individuals have the urge to always maintain relationships, even in critical conditions.

3 Labels: Intimacy

Definition: The feeling of wanting to be close, wanting to always be in touch, forming bonds with loved ones.

\section{Indicators:}

- Feeling lonely when not with their partner

- Having an urge to want to interact with their partner

- Feeling worried when not getting news from their partner

- Getting closer to the spouse's family

4 Labels: Trust

Definition: A belief, concern for the partner and the individual that the partner can rely on in any situation.

\section{Indicators:}

- Always loyal to their partner

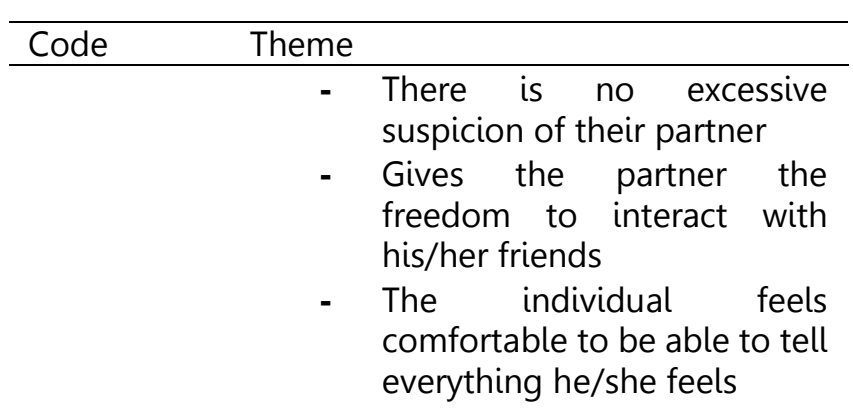

5 Labels: Passion

Definition: Encouragement that leads to a passionate relationship and also demonstrated sexual attraction.

Indicators:

- Praise the appearance of the partner

- Want to always be close physically and nonphysically

- Do physical touches as a form of affection

- Give romantic words to the partner

6 Label: Love

Definition: A description of how much affection, respect, and admiration individuals have for their partner.

Indicators:

- Have a sense of attraction to their partner both physically and their characteristics

- Have a sense of affection and care for their partner

- The urge to give attention to their partner

Strengthening the credibility used in this study uses triangulation techniques to improve the likelihood of findings and interpretations that will be reliable (Ahmadi, 2014). In this study, the triangulation model used is the data triangulation model and the theoretical triangulation model. Data triangulation is the use of multiple data sources in a study. Theoretical triangulation uses multiple perspectives to interpret a single data set (Ahmadi, 2014). 


\section{Results and Discussion}

Relationship quality is generally used to refer to how happy or satisfied a person is in their relationship and how well partners get along together (Reynolds, Houlston, and Coleman, 2014). In relationship quality, several dimensions influence, Hassebrauck and Fehr (2002) suggest that relationship quality has 4 dimensions, namely: Intimacy, Agreement, Independence, and Sexuality. Intimacy is the process by which people feel understood, validated, and cared for in a relationship. Agreement refers more to common ground, common goals, and common activities, other than just a few fights. Independence refers to autonomy, maintaining individuality, and having freedom. Sexuality is similar to Sternberg's arousal component and is also an element of the prototype of love (Hassebrauck and Fehr, 2002).

According to Fletcher, Simpson, and Thomas (2000), there are 6 components in assessing relationship quality. These components have been arranged and theoretically are representative to be used as an assessment related to the quality of the relationship with the partner, namely:

\section{Relationship Satisfaction}

The state in which the couple feels the relationship is going according to what they expect, the extent to which the partner meets the most important needs of the individual can lead to the achievement of happiness in the relationship. This is indicated by the following behaviors:

- Individuals can fulfill the expectations of their partners
- Individuals can explain the needs of their partners

- Individuals can be happy every time their partners achieve certain achievements

\section{Commitment}

Decisions to love others and try to maintain that love continuously by being loyal to their partners. This is indicated by the following behaviors:

- Individuals keep promises that have been discussed

- Individuals have no desire to cheat

- Individuals have no urge to lie

- Individuals have an urge to always maintain relationships even in critical conditions

\section{Intimacy}

The feeling of wanting to be close, wanting to always be in touch, forming bonds with loved ones. This is indicated by the following behaviors:

- Feeling lonely when not with their partner

- Have an urge to want to interact with a partner

- There is a feeling of worry when not getting news from a partner

\section{Trust}

A belief, concern for the partner and the individual can be relied on by the partner in any situation. This is shown by the following behaviors:

- Always loyal to your partner

- There is no excessive suspicion of your partner

- Give your freedom to interact with his friends

- Individuals feel comfortable being able to tell everything they feel 


\section{Passion}

The encouragement that leads to a passionate relationship and is also shown by sexual attraction. This is indicated by the following behavior:

- Praising the appearance of a couple

- Want to stay physically close

- Doing physical touches as a form of compassion, giving words to the couple romantic

6. Love

Picture of how affection, respect, and admiration an individual partner. This is indicated by the following behaviors:

- Having a sense of attraction to a partner both physically and in terms of characteristics

- Have a sense of affection and care for a partner

- Encouragement to pay attention to a partner.

These components are used in assessing the quality of the couple's relationship. Researchers used six components in assessing the quality of relationships from Fletcher, Simpson, and Thomas (2000) because these components have been arranged and theoretically are representative to be used as an assessment related to the quality of relationships with partners. Based on these components, the results of the theory-driven thematic analysis are obtained as follows: (table 2)

Table 2

Results of The Theory-Driven Thematic Analysis of Respondents 1

\begin{tabular}{lll} 
No. Theme & Description \\
\hline 1. &
\end{tabular}

No. Theme
Relationship
Satisfaction

Description

Respondent $1(\mathrm{R})$ has a positive effect in undergoing LDR and also has satisfaction in his current relationship. $\mathrm{R}$ can fulfill the expectations of his partner, provide understanding for each other, $R$ also says that $R$ gets a partner who can accept the activities he does. However, R and his partner often talk about foresight in their relationship. $\mathrm{R}$ has an uncomfortable feeling in undergoing LDR because it makes him have excessive thoughts about his partner.

2. Commitment R's form of commitment with his partner can be seen from giving each other news through intense communication, being open to partners, keeping promises that have been discussed, and maintaining relationships even in critical conditions. Not only that, but $\mathrm{R}$ also said that he and his partner should enjoy the LDR situation because of the commitment they had made together.

3. Intimacy In a long-distance relationship, $\mathrm{R}$ feels lonely and has an uncomfortable feeling when he is not with his partner. $\mathrm{R}$ and his partner build intimacy by communicating with their partner by telling daily activities. This, according to $R$, can treat longing for his partner. Not only with his partner, but $R$ also has a close relationship with his partner's family, especially with his sister. 
No. Theme

4. Trust

5. Passion

6. Love
The form of R's trust in his partner can be seen from $R$ giving his couple the freedom to interact with their friends and not having excessive suspicion of their partner by expressing their views and supporting their partner's activities. Although $\mathrm{R}$ provides flexibility, sometimes $\mathrm{R}$ feels uncomfortable because his partner is in an environment where boys are more dominant than girls. $R$ said that being open to each other can foster trust in each other.

R's drive that leads to a passionate relationship can be seen from R's desire to always be physically close to his partner. $\mathrm{R}$ said that he was very happy when he met his partner because $R$ often did activities together before LDR. Meanwhile, $R$ has to do his activities. This makes $R$ have feelings of longing for his partner.

$R$ shows feelings of affection, respect, and admiration for their partner through physical attraction and characteristics. $\mathrm{R}$ also said that his feelings for his partner have not changed and even remain comfortable even though they are undergoing LDR. According to $\mathrm{R}$, the only thing that changes is the activity he does because $R$ has to do the activity without his partner.

From the thematic analysis above, it appears that respondent one shows a relationship satisfaction component in the form of being able to meet the expectations desired by his partner. Respondents often talk about future views and share their understanding with each other. This is a positive impact of the ongoing LDR. However, there is an uncomfortable feeling that makes the relationship satisfaction felt by the respondent not optimal. While in the aspect of commitment, respondents showed it by giving each other news intensely, being open to each other, and keeping promises that had been made previously. These efforts have an impact on their success in maintaining relationships in the most critical conditions.

Then on the aspect of intimacy, respondents feel lonely when not with their partner. One of the ways that respondents used to maintain their intimacy was by telling their daily experiences intensely. Respondents are not only close to their partner but also close to their partner's siblings. While in the trust component, respondents give their partners the freedom to socialize, while still telling each other their experiences. However, there are still concerns that arise in the minds of respondents because their partner's environment is dominated by men. In the passion component, respondents have physical closeness with their partners. So that after LDR, the subject feels a longing for his partner. In the last component, namely the love component, the subject shows that feelings of affection, admiration, and respect for their partner are maintained, even though they are no longer active together (Fletcher, Simpson, \& Thomas, 2000).

Table 3

Results of The Theory-Driven Thematic Analysis of Respondents 2

\begin{tabular}{|l|l|l|}
\hline No & \multicolumn{1}{|c|}{ Theme } & \multicolumn{1}{|c|}{ Description } \\
\hline 1. & $\begin{array}{l}\text { Relationship } \\
\text { Satisfaction }\end{array}$ & $\begin{array}{l}\text { Respondent } 2 \text { (M) } \\
\text { feels that the need to } \\
\text { communicate } \\
\text { intensely with his } \\
\text { partner must be } \\
\text { fulfilled during the } \\
\text { LDR phase to obtain } \\
\text { a satisfactory long- } \\
\text { distance relationship. }\end{array}$ \\
\hline
\end{tabular}




\begin{tabular}{|c|c|c|}
\hline No & Theme & Description \\
\hline & & $\begin{array}{l}\text { It can be seen from } \\
\text { the verbal expression } \\
\text { of the subject who is } \\
\text { worried that if he } \\
\text { does not } \\
\text { communicate } \\
\text { intensely, he will } \\
\text { forget his partner's } \\
\text { face. L also includes } \\
\text { individuals who are } \\
\text { less appreciative } \\
\text { when their partner } \\
\text { achieves certain } \\
\text { achievements. This } \\
\text { can be seen from the } \\
\text { response of the } \\
\text { subject who did not } \\
\text { provide support } \\
\text { when his partner } \\
\text { succeeded in } \\
\text { mastering a new } \\
\text { language and had the } \\
\text { opportunity } \\
\text { extend his study } \\
\text { period in Malaysia. }\end{array}$ \\
\hline 2. & Commitment & $\begin{array}{l}\mathrm{L} \text { and his partner } \\
\text { commit to paying } \\
\text { attention to each } \\
\text { other, open up to } \\
\text { each other, maintain } \\
\text { relationships under } \\
\text { any conditions. This } \\
\text { commitment appears } \\
\text { in the form of } \\
\text { constantly reminding } \\
\text { each other to tell } \\
\text { about the problems } \\
\text { they are facing, } \\
\text { telling their condition } \\
\text { without being asked } \\
\text { by their partner, } \\
\text { willing to share their } \\
\text { daily experiences, } \\
\text { especially things that } \\
\text { are important. } L \text { and } \\
\text { his partner also try to } \\
\text { keep any fights that } \\
\text { occur from ending } \\
\text { the relationship. }\end{array}$ \\
\hline 3. & Intimacy & $\begin{array}{l}\mathrm{L} \text { feels worried } \\
\text { because he doesn't } \\
\text { get news from his } \\
\text { partner. It was very } \\
\text { clear when L said that } \\
\text { worries and conflicts } \\
\text { arise due to the } \\
\text { reduced intensity of } \\
\text { communication. } \mathrm{L} \\
\text { also feels lonely when }\end{array}$ \\
\hline
\end{tabular}

\begin{tabular}{|c|c|c|}
\hline No & Theme & Description \\
\hline & & $\begin{array}{l}\text { not with his partner. } L \\
\text { has the urge to want } \\
\text { to interact with a } \\
\text { partner. L has a fear } \\
\text { of meeting his } \\
\text { partner's family. L has } \\
\text { a certain view } \\
\text { regarding the } \\
\text { couple's family that } \\
\text { causes the subject to } \\
\text { feel unprepared }\end{array}$ \\
\hline 4. & Trust & $\begin{array}{l}\text { L has excessive } \\
\text { suspicion of a } \\
\text { partner. It was very } \\
\text { obvious when L said } \\
\text { that he believed less } \\
\text { and who believed } \\
\text { more was his partner. } \\
\mathrm{L} \text { also said that he } \\
\text { believed he was } \\
\text { forced to because of } \\
\text { circumstances. This } \\
\text { happened at the } \\
\text { beginning of the LDR } \\
\text { period but as time } \\
\text { passed, the forced } \\
\text { trust was more } \\
\text { towards ignoring } \\
\text { when there was no } \\
\text { news. L also tends not } \\
\text { to talk about how he } \\
\text { really feels. This can } \\
\text { be seen when his } \\
\text { partner tells that he is } \\
\text { often made fun of by } \\
\text { being paired up with } \\
\text { his female friends } \\
\text { who are there, L } \\
\text { tends to be angry and } \\
\text { when asked why, he } \\
\text { is more unwilling to } \\
\text { answer and hides his } \\
\text { feelings }\end{array}$ \\
\hline 5. & Passion & $\begin{array}{l}\mathrm{L} \text { wants to be } \\
\text { physically close to his } \\
\text { partner even in LDR } \\
\text { conditions. This can } \\
\text { be seen when L said } \\
\text { he wanted a video } \\
\text { call, although in the } \\
\text { end when LDR this } \\
\text { rarely happened } \\
\text { because he was tired } \\
\text { of each other's } \\
\text { activities. Finally, } \\
\text { more often only via } \\
\text { chat. }\end{array}$ \\
\hline 6. & Love & $\begin{array}{l}\mathrm{L} \text { wants to get more } \\
\text { attention from his }\end{array}$ \\
\hline
\end{tabular}




\begin{tabular}{|l|l|l|}
\hline No & Theme & \multicolumn{1}{|c|}{ Description } \\
& & $\begin{array}{l}\text { partner. This is } \\
\text { evident from the } \\
\text { request to be } \\
\text { contacted. L also } \\
\text { wants to be } \\
\text { understood by his } \\
\text { partner. }\end{array}$ \\
\hline
\end{tabular}

From the thematic analysis above, the respondent's relationship satisfaction component shows that intense communication is a major need in LDR relationships because respondents are worried that they will forget the feelings that have been nurtured so far. Respondents also did not appreciate the achievements of their partners, including the studies they had undertaken. While in the aspect of commitment, respondents pay attention to each other, tell each other experiences and problems they face, and keep every quarrel that occurs does not end in a breakup. In the aspect of intimacy, respondents showed a sense of worry due to the reduced intensity of communication and togetherness. Respondents have certain concerns when introduced to their partner's family. In the trust component, the respondent has excessive suspicion of his partner so that this results in a response pattern when he does not get news and does not want to talk about what he really feels. While in the passion component, respondents want to be physically close to their partner during LDR through video calls. However, in reality, they can only be close verbally through media chat. Meanwhile, in the aspect of love, respondents showed different indicators from the grand theory (Fletcher, Simpson, and Thomas, 2000). The indicator is the desire to get more attention from partners who are shown anger when they get less attention and care from their partners.

\section{Conclusion}

Based on the results of this study, it can be concluded that the relationship quality of each early adult who has a longdistance relationship is different. There are 6 interrelated components in forming relationship quality, namely relationship satisfaction, commitment, intimacy, trust, desire, and love. In establishing a longdistance relationship, intimacy is not obtained because it does not meet in person directly. However, intimacy can still be pursued by maintaining the intensity of communication with a partner. Therefore, communication is the key to building quality relationships in couples who are in long-distance relationships. This study provides an overview of the quality of early adult relationships who have longdistance relationships. In addition, this study provides an overview of what components need to be considered to build a harmonious relationship and for individuals in long-distance relationships or individuals considering long-distance relationships.

\section{Suggestions}

Suggestions that can be given by researchers following the results of research that have been carried out are as follows: Suggestions for further research. It is hoped that the subject of the focus of the pair can be obtained so that it can obtain data from two possible different points of view. Future researchers are expected to examine factors that moderate or mediate relationship quality variables, such as perceptions of shared goals, social support, and attachment. Suggestions for individuals who undergo long-distance relationships are expected 
to pay attention to aspects in improving the quality of relationships. 


\section{References}

"Long-Distance

Relationship

Mungkinkah?". (2011, November 1).

Koran Jakarta. https://m.koranjakarta.com/?id=75047\&mode_ber itadetail $=1$

Aanstoos, C. M., Serlin, I., and Greening, T. (2000). A History of Division 32 (Humanistic Psychology). In D. A. Dewsbury (Eds.), $A$ History of Division $32 \quad$ (Humanistic Psychology). In Unification through division: Histories of the divisions of the American Psychological Association. American Psychological Association. https://psycnet.apa.org/doi/10.103 7/10356-004

Ahmadi, R. (2014). Metodologi Penelitian Kualitatif. Ar-Ruzz Media.

Arnett, J. J. (2000). Emerging Adulthood. A Theory of Development from the Late Teens through the Twenties. American Psychologist, 55(5), 469480.

https://psycnet.apa.org/doi/10.103 7/0003-066X.55.5.469

Cieleszky, K. (2017). Long-Distance Intimacy: How Intimacy in LongDistance Relationships Change Over Erasmus+Exchange. [Master thesis, Karlstad University]. http://www.diva-

portal.org/smash/record.jsf?pid = di va2\%3A1136061\&dswid $=-1877$

Creswell, J. W. (2007). Qualitative Inquiry and Research Design: Choosing among Five Approaches. Sage Publications, Inc.

Fletcher, G. J., Simpson, J. A., and Thomas, G. (2000). The Measurement of Perceived Relationship Quality Components: A Confirmatory Factor Analytic Approach. Personality and Social Psychology Bulletin, 26(3). https://psycnet.apa.org/doi/10.117 7/0146167200265007

Guldner, G. T., and Swensen, C. H. (1995). Time Spent Together and Relationship Quality: Long-distance Relationships As A Test Case. Journal of Social and Personal Relationships, 12(2). https://psycnet.apa.org/doi/10.117 7/0265407595122010

Hassebrauck, M., \& Fehr, B. (2002). Dimensions of Relationship Quality. Personal Relationships, 9(3), 253270. https://psycnet.apa.org/doi/10.111 1/1475-6811.00017

Holmes, M. (2004). An Equal Distance? Individualization, Gender, And Intimacy In Distance. Wiley Online Library. https://doi.org/10.1111/j.1467954X.2004.00464.x

Kelmer, G., Rhoades, G. K., Stanley, S., \& Markman, H. J. (2013). Relationship Quality, Commitment, and Stability in Long-Distance Relationships. Family Process, 52(2). https://doi.org/10.1111/j.15455300.2012.01418.x

Kidenda, T. J. (2002). A Study of Cultural Variability and Relational Maintenance Behaviors for International and Domestic Proximal and Long-Distance Interpersonal

Relationships. [Master Thesis University of North Texas]

Lesmana, S. (2010). Studi Deskriptif Mengenai Komitmen Pada Mahasiswa Yang Menjalani Hubungan Pacaran Jarak Jauh di Universitas " $X$ " Bandung. [Undergraduate thesis, Universitas Kristen Maranatha]. http://repository.maranatha.edu/1 1190/ 
Manampiring, H. (2014, July 23). Laporan Survey LDR Nasional. The Laughing Phoenix.

https://henrymanampiring.com/20

12/11/11/laporan-survey-ldrnasional/

Moleong, L. J. (2013). Metodologi Penelitian Kualitatif. PT Remaja Rosdakarya.

Neustaedter, C., \& Greenberg, S. (2011). Intimacy in Long-Distance Relationship over Video Chat. Canada, Computer Science. Canada: Summit. https://summit.sfu.ca/item/10361

Okfriana, R. (2016). Pola Komunikasi Pasangan yang Menjalani Hubungan Pacaran Jarak Jauh. [Undergraduate Thesis, Universitas Sebelas Maret]. https://eprints.uns.ac.id/32368/1/D 1214066_pendahuluan.pdf

Parrenas, R. (2005). Long-Distance Intimacy: Class, Gender and Intergenerational Relations Between Mothers and Children in Filipino Transnational Families. Wiley Online Library, 5(4). https://doi.org/10.1111/j.14710374.2005.00122.x

Patton, M. Q. (2002). Qualitative Research and Evaluation Methods. Sage Publications.

Reynolds, J., Houlston, C., \& Coleman, L. (2014). Understanding Relationship Quality. OnePlusOne.

Simanjuntak, J. (2011, June 26). Pacaran Jarak Jauh. Kompasiana. https://www.kompasiana.com/julia ntosimanjuntak/5500e573813311e b18fa7eb1/pacaran-jarak\%20jauh

Yudistriana, K., Basuki, A. H., \& Harsanti, I. (2010). Intimasi Pada Pria Dewasa Awal yang berpacaran Jarak Jauh Beda Kota. Jurnal Psikologi, 3(2). https://ejournal.gunadarma.ac.id/in dex.php/psiko/article/view/237/17 8 